\title{
An Investigation of Metaphoric Cognition of First-Year College Students at Xinxiang Medical University, China
}

\author{
Zhang $\operatorname{Ran}^{1,2} \&$ Mogana Dhamotharan ${ }^{1}$ \\ ${ }^{1}$ Faculty of Education, SEGi University, Kota Damansara, Selangor, Malaysia \\ ${ }^{2}$ Foreign Language Department, Xinxiang Medical University, Henan, China \\ Correspondence: Ran Zhang, Faculty of Education, SEGi University, Kota Damansara, Selangor, Malaysia.
}

Received: May 23, 2020

doi: $10.5539 /$ elt.v13n7p111
Accepted: June 26, 2020

Online Published: June 28, 2020

URL: https://doi.org/10.5539/elt.v13n7p111

\begin{abstract}
The "College English Teaching Reform Project", issued by the Chinese Ministry of Education aims to strengthen the practical English instruction and improve the English language proficiency of the college students (Ministry of Education, 2007). However, the problem of "naturalness" in handling English by the college students still exists due to imbalanced language forms and concepts between their native language (Chinese) and target language (English). Since metaphor was referred to as only a figure of speech and often compared with simile in high schools, many students do not realize that it also can be a powerful cognitive tool. In order to ascertain the students' metaphor cognition competence in General English and Medical English, a metaphor cognition questionnaire was distributed in a class and the results obtained show that the respondents can readily recognize the existence of metaphors in General English and the teachers' instruction, and they know the essential function of metaphors. The results further show that many respondents understand metaphors in terms of the context rather than the images. However, only about half of them can effectively use metaphors in their writing and speaking.
\end{abstract}

Keywords: Metaphor, Metaphoric Cognition, General English, Medical English

\section{Introduction}

Metaphor accounts for about 10 per cent of everyday speech, says James Geary (2011, pp. 5-6). According to George Lakoff and Mark Johnson's (1980) Metaphors We Live By, metaphor is not simply a matter of word or linguistic expression, but of concept, of thinking of one thing in terms of another. Examples of this include when we talk and think about life in terms of journey, about argument in terms of war, about ideas in terms of food, about social organizations in terms of plants, and many more. Lakoff and Johnson claim that as the concept and activity are structured metaphorically, the language is structured metaphorically $(1980, \mathrm{p} .6)$. The cognitive theory of metaphor shows that the abilities of interpreting and producing metaphor in the target language are vital for language learning. As a ubiquitous phenomenon in language, metaphor is the motive power of the language system's development and change, and a leading way to close the gap between the old and new knowledge of the students. For College EFL (English as a Foreign Language) students, metaphors help and enable them to recognize word formation rules and develop their metaphor analysis competence towards medical terms. As for teachers, it likens to teaching the method of fishing rather than offering the fish. Teachers should help the students master their Medical English by raising the level of metaphor awareness in Medical English and cultivating their metaphorical competence.

Besides, metaphors can facilitate communication by using familiar concepts to describe the abstract and complex concepts in medicine. Metaphors can bridge the understanding between the known and the unknown. Hence, it can be used as an effective tool to enhance the understanding of diseases which are complex and abstract. Good metaphors can vividly describe a medical condition, thereby helping the patients understand their diseases and treatments easily.

Therefore, it becomes essential to investigate the students' current level of metaphoric cognition and supplement the general English language teaching with suitable metaphor-enriched English teaching. This research aims to investigate the current level of metaphor cognition ability of the first-year college students at Xinxiang Medical University, China. 


\section{Literature review}

\subsection{Study of Metaphor}

There are several theories prevalent in the study of metaphors. Among the metaphor theories, two outstanding ones are Aristotle's comparison theory and Quintilian's substitution theory; both view metaphor as a figure of speech. By and by, the focus of metaphor gets transferred to the cognitive study, and Lakoff and Johnson (2003) in an afterword to their 1980 book, Metaphors We Live By, have come up with the conceptual metaphor theory which has become a dominant content in today's study of metaphor. The key feature of the conceptual metaphor is that the metaphors are conceptual and are not just a function of language. These conceptual metaphors are grounded in our experiences. In other words, the experiences we gain in life shape the metaphors that we use to explain various concepts. A metaphorical thought is unavoidable in our day today life and the process is largely unconscious. Though abstract thoughts have a literal core, they are extended by metaphors; our understandings of them are deepened by metaphors. We live our very lives every day on the basis of inferences we derive through metaphors (Lakoff \& Johnson, 2003).

\subsection{Metaphors in Medicine}

In the existing research, much of the medical language is built around metaphors both in oral (Roche, 2002; Gibbs and Franks, 2002; Semino, 2004; Pena and Andrade-Filho, 2010; Zumla, 2012) and written usage (Knudsen, 2005; Calsamiglia \& van Dijk, 2004; Divasson \& León, 2006). Although metaphors are pervasive in our languages, not much attention is paid to metaphors in medicine, let alone applying metaphors to Medical English instruction. There are quite a few important reasons for including metaphor oriented instruction in Medical English. First, metaphor is an important way of language generation, as well as a way to develop word meanings. Second, when communicating with patients, medical students often have problems in using and comprehending metaphors. Using metaphors may help them become good communicators in clinical practice (Sontag, 1978; Reisfield and Wilson, 2004; Vyjeyanthi, 2008; Casarett, 2010). As Anatole Broyard describes, "metaphors may be as necessary to illness as they are to literature, as comforting to the patient as his own bathrobe and slippers." $(1990$, p.206). It is quite certain that metaphors can bring forth empathy between the doctors and patients which is one of the vital elements of communication for proper health care.

\section{Research Method}

This research adopts the qualitative research to investigate the metaphoric cognition ability of medical students via a Metaphor Cognition Questionnaire. It is a modification of Wei Yaozhang's questionnaire, investigating the influence of cognitive competence of the students in understanding and generating metaphors (Wei, 2007). There are three parts and the participants are required to complete them within 60 minutes. At the very beginning of the test, there is a rubric in native language, that is, Chinese, briefly explaining through simple examples what a metaphor is. The first part consists of the demographic information of the respondents. Part two consists of 10 items referring to their identification and understanding of metaphors in General English. Part three is composed of 8 items which refer to the understanding of medical metaphors. Since the purpose of the research is to learn about the participants' understanding of metaphors, the five-point Likert scale is truncated into 4 categories to eliminate the "neutral" option in a "forced choice" survey scale. The four scales are: strongly disagree (SD), disagree (D), agree (A) and strongly agree (SA). Numbers are assigned to these four scales, namely, 1 = strongly disagree, 2 = disagree, $3=$ agree, and $4=$ strongly agree. The participants are required to choose one of these, based on their understanding. The data is analyzed with SPSS (22.0).

\section{Findings}

The Metaphoric Cognition Questionnaire was distributed to 150 first-year college students of the researcher's class. All these students major in Clinical Medicine. 144 of them returned the completed questionnaires, pegging the recovery rate at $96 \%$. The Demographic information for this questionnaire is presented as follows:

\subsection{Demographic Profile of Respondents}

The demographic information of 144 respondents includes age, gender, major and NCEE scores. The age of the 144 respondents is shown in Table1. 
Table 1. Age of Respondents

\begin{tabular}{lcc}
\hline Age & Frequency & Percentage \\
\hline 17 & 81 & 56.3 \\
18 & 42 & 29.1 \\
19 & 15 & 10.4 \\
20 & 3 & 2.1 \\
21 & 3 & 2.1 \\
Total & 144 & 100.0 \\
\hline
\end{tabular}

From Table 1, it is evident that students in the 17 year old age group form the majority (56.3\%). There are 42 eighteen year olds (29.1\%), 15 nineteen year olds (10.4\%), 3 twenty year olds and 3 twentyone year olds (both $3.1 \%)$.

Gender categorization is given in Table 2:

Table 2. Gender of Respondents

\begin{tabular}{lcc}
\hline Gender & Frequency & Percentage \\
\hline Male & 62 & 43.1 \\
Female & 82 & 56.9 \\
Total & 144 & 100.0 \\
\hline
\end{tabular}

Of the 144 respondents, 82 respondents (56.9\%) are females and 62 respondents $(43.1 \%)$ are males.

The percentage details of the achievement of the students in English are given in Table 3.

Table 3. English Achievement of Respondents

\begin{tabular}{ccc}
\hline English Achievement & (NCEE English score) & Questionnaire \\
\hline Score Group & Frequency & Percentage \\
\hline$<90$ & 5 & 3.5 \\
$90-100$ & 6 & 4.2 \\
$101-110$ & 21 & 14.6 \\
$111-120$ & 37 & 25.7 \\
$121-130$ & 58 & 40.3 \\
$>130$ & 17 & 11.8 \\
Total & 144 & 100.0
\end{tabular}

Note. NCEE=National College Entrance Examination. The full score of NCEE is 150 .

For analyzing the English Achievement, 144 respondents were required to write down the marks they scored in the National College Entrance Exam (NCEE), English. They are divided into six groups. The 121-130 group is the largest with $40.3 \%$; the $111-120$ group is the second with $25.7 \%$; the $101-110$ group is $14.6 \%$; the above 130 group is $11.8 \%$; the $90-100$ group is $4.2 \%$, and the smallest less than 90 group is $3.5 \%$. From the percentage data, it is evident that the scores in English of the 111-120 group and the 121-130 group total 66\%, which points to the fact that their English level is relatively good. 


\subsection{Part 1: Metaphoric Cognition}

Table 4. Percentage of Items on Metaphor Identification

\begin{tabular}{lcccc}
\hline \multicolumn{1}{c}{ Items } & $\mathrm{SD}$ & $\mathrm{D}$ & $\mathrm{A}$ & $\mathrm{SA}$ \\
\cline { 2 - 4 } & $(\%)$ & $(\%)$ & $(\%)$ & $(\%)$ \\
\hline & 6.2 & 25.0 & 52.1 & 16.7 \\
\hline $\begin{array}{l}\text { 1. I know that there are many metaphors in general English. } \\
\text { 2. I know that metaphors in English articles can make language more }\end{array}$ & 2.8 & 6.3 & 45.1 & 45.8 \\
vivid. & 7.6 & 66.7 & 22.9 & 2.8 \\
3. I find teachers always use metaphors in their instruction. & 2.8 & 19.4 & 50.7 & 27.1 \\
$\begin{array}{l}\text { 4. I know that some conceptual metaphors in English are different from } \\
\text { those in Chinese. }\end{array}$ & & & & \\
5. I know that some metaphorical expressions in English are different & 0.7 & 16.0 & 53.5 & 29.9 \\
from those in Chinese. & & & & \\
6. The image of the compared object will immediately flash in my & 13.2 & 47.9 & 29.9 & 9.0 \\
mind when I find metaphors. & & & & \\
7. I will understand metaphors in the context of the texts. & 2.1 & 16.0 & 52.1 & 29.9 \\
$\begin{array}{l}\text { 8. I will consciously apply metaphors which I have learned in the } \\
\text { classroom to my writing. }\end{array}$ & 11.1 & 54.9 & 31.2 & 2.8 \\
$\begin{array}{l}\text { 9. When communicating with English native speakers in English, I } \\
\text { often discuss metaphors with them. }\end{array}$ & 35.4 & 52.8 & 8.3 & 3.5 \\
10. I often try to express my ideas new metaphors. & 13.2 & 50.7 & 29.9 & 6.3 \\
\hline
\end{tabular}

Note. $\mathrm{SD}=$ Strongly Disagree, $\mathrm{D}=$ Disagree, $\mathrm{A}=$ Agree, $\mathrm{SA}=$ Strongly Agree.

Question 1 shows that $68.8 \%$ of the respondents know that there are many metaphors in general English and 31.2\% respondents do not know about it, which indicates the majority of respondents know the existence of metaphors. Question 2 refers to the function of metaphors. 90.9\% of the respondents affirm that they are aware of the occurrence of metaphors while only $9.1 \%$ disagree. Question 3 refers to the teacher's usage of metaphors. $25.7 \%$ of the respondents think their teachers always use metaphors in their teaching, while $74.3 \%$ of the respondents disagree. This shows quite a different view on teachers' use of metaphors in teaching. Question 4 and 5 relate to the difference between English metaphors and Chinese metaphors. $77.8 \%$ of the respondents are aware of the difference while $22.2 \%$ are not. As for metaphorical expressions, $83.4 \%$ of the respondents are aware of the difference while $16.6 \%$ are not. Question 6 and 7 deal with the understanding approaches of metaphors. $38.9 \%$ of the respondents can associate the images of compared objects, while $61.1 \%$ cannot. $82 \%$ of the respondents understand metaphors in the context of the texts, while only 18\% do not. Comparing question 6 and 7, it may be found that the respondents are more likely to understand metaphors through context rather than through the images. Question 8,9 and 10 relate to the application of metaphors. Although the respondents think that metaphors are important and commonplace in daily life, more than half of the respondents do not use it in their writing and speaking. $66 \%$ of the respondents do not use metaphors in their writing and $88.2 \%$ of them do not use metaphors to communicate with the English native speakers. $63.9 \%$ of them do not think of creating new metaphors to express their ideas. The following figure is the histogram of the percentage of students' metaphoric cognition: 


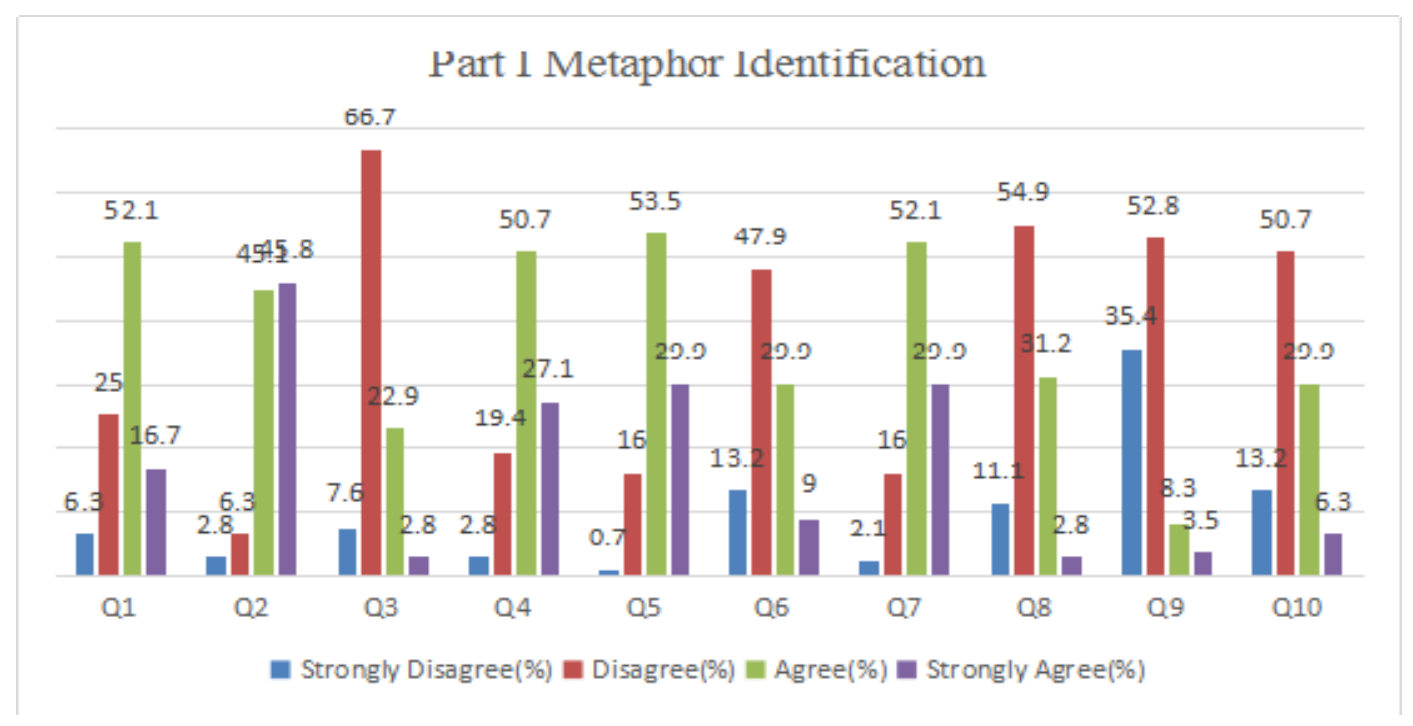

Figure 1. Percentage of items on metaphoric cognition

In brief, the results show that the respondents are well aware of the existence of metaphors in General English and the teaching in classes, and they understand the essential function of metaphors, in the process of understanding. It is to be noted that most of the respondents understand it in terms of the context rather than the images. However, about half of them are capable of using metaphors in their writing and speaking.

\subsection{Metaphor and Medical Metaphor}

Table 5. Percentage of Items on Metaphors and Medical English

\begin{tabular}{|c|c|c|c|c|}
\hline \multirow[t]{2}{*}{ Items } & SD & D & A & SA \\
\hline & $(\%)$ & $(\%)$ & $(\%)$ & $(\%)$ \\
\hline 11. I know that there are many metaphors in medical English. & 14.6 & 48.6 & 25.0 & 11.8 \\
\hline 12. I am sensitive to metaphors in the articles in medical journals. & 20.8 & 63.9 & 11.1 & 4.2 \\
\hline 13. I know that metaphors help me to memorize medical words. & 4.2 & 19.4 & 58.3 & 18.1 \\
\hline 14. Metaphors help me to understand the medical terms. & 2.1 & 17.4 & 53.5 & 27.1 \\
\hline 15. Metaphorical expressions help me to understand the illness. & 0.7 & 16.0 & 54.2 & 29.2 \\
\hline $\begin{array}{l}\text { 16. I think it is interesting to understand medical articles from the } \\
\text { perspective of metaphors. }\end{array}$ & 2.1 & 14.6 & 46.5 & 36.8 \\
\hline $\begin{array}{l}\text { 17. I realize that using metaphors can express the phenomenon that } \\
\text { some non-metaphorical languages cannot express. }\end{array}$ & 1.4 & 9.0 & 51.4 & 38.2 \\
\hline $\begin{array}{l}\text { 18. I will use metaphors to explain conditions of illness to my patients } \\
\text { in future. }\end{array}$ & 6.3 & 11.8 & 56.9 & 25.0 \\
\hline
\end{tabular}

Note. $\mathrm{SD}=$ Strongly Disagree, $\mathrm{D}=$ Disagree, $\mathrm{A}=$ Agree, $\mathrm{SA}=$ Strongly Agree.

Question 11 and 12 relate to the respondents' cognition of medical metaphors. Question 11 shows that only $36.8 \%$ of the respondents know that there are many metaphors in Medical English, compared to $78.8 \%$ of the respondents of General English. It obviously indicates that a smaller number of respondents know the existence of medical metaphors. Question 12 shows that only $15.3 \%$ respondents are sensitive to medical metaphors, which implies that $84.7 \%$ of the respondents cannot identify medical metaphors. Question 13 to 17 relate to the functions of medical metaphors. $86.4 \%$ of the respondents know that metaphors contribute to the clear understanding of medical words. $80.7 \%$ of the respondents believe it contributes to memorizing medical words, $86.2 \%$ respondents affirm that it helps to understand the illness, $79.6 \%$ respondents think it is an interesting approach to understand the medical articles, and $83.3 \%$ respondents believe a metaphor can well express a phenomenon which some non-metaphorical one cannot. Question 18 deals with the future application of metaphors in explaining conditions of illness to 
patients. $81.9 \%$ of the respondents have chosen to apply it in future which fact implies that most of the respondents have realized the importance of metaphors.

The following figure is the histogram of the percentage of students' cognition of medical metaphors:

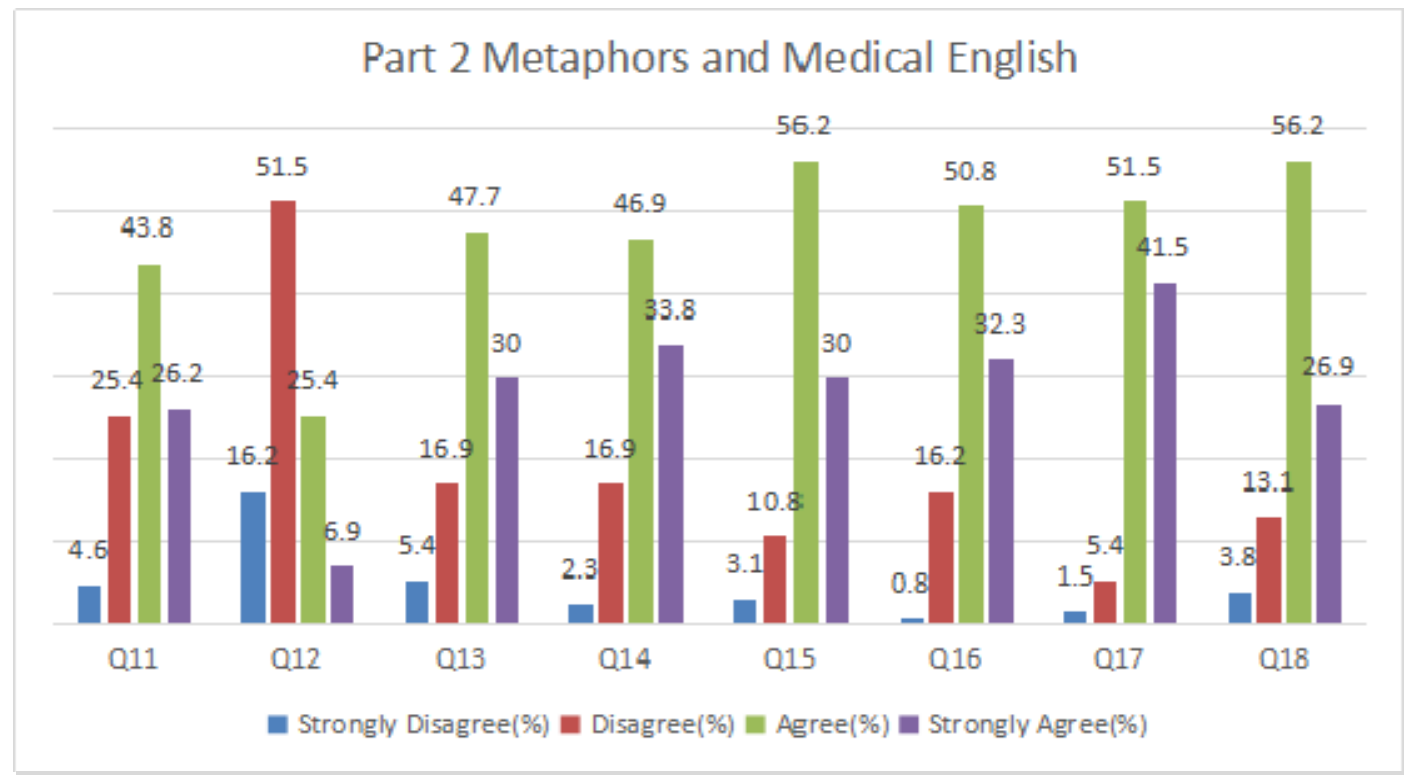

Figure 2. Percentage of Items on Medical Metaphors

In brief, comparing with $78.8 \%$ respondents who know there are many metaphors in general English, only $36.8 \%$ respondents know of metaphors in medical English. Besides, only $15.3 \%$ respondents are sensitive to medical metaphors, a fact which indicates their ignorance of metaphor usage in Medical English. Although nearly a half of the respondents are not familiar with medical metaphors, they have confirmed the role of metaphors in understanding and memorizing medical words and diseases. $81.9 \%$ respondents assure that they will use metaphors while communicating in their future careers.

\section{Conclusion}

123 of the 144 respondents are 17 and 18 years old and they are $85.4 \%$ of the total respondents. For the National College Entrance Examination the maximum mark is 150. 58 respondents (40.3\%) are in 121-130 score level which forms the largest percentage of all the six score levels. 37 respondents (25.7\%) are in 111-120 score level. Both these two groups together are $66 \%$ of all the respondents which means their English level are relatively good.

However, as for their cognition level of general metaphors, the respondents showed their disagreement with some items. On the one hand, $78.8 \%$ of the respondents know that there are many metaphors in general English. On the other hand, $74.3 \%$ of the respondents hold the view that teachers do not always use metaphors in their teaching. $61.1 \%$ of the respondents cannot associate the image of the compared object when they come across a metaphor. $66 \%$ respondents will not consciously apply metaphors which they have learned in the classroom to their writing. $88.2 \%$ respondents do not use metaphors frequently when they communicate in English with native English speakers. $63.9 \%$ respondents do not often try to express their ideas by using new metaphors. For the cognition of medical metaphors, $63.2 \%$ respondents do not know the pervasive existence of metaphors in Medical English. $84.7 \%$ respondents are not sensitive to metaphors in the medical journals. However, respondents have confirmed the significance of metaphors in understanding and memorizing medical terms, and diseases. $81.9 \%$ respondents will use metaphors to explain the conditions of their illness to patients in future.

In conclusion, the metaphor-based instruction should be implemented in EFL curricula, providing medical students with an appropriate approach in order to improve their English proficiency (Danesi, 1992; Kecskes, 2006), to increase their skills in the interpretation of metaphors (Johnson \& Rosano, 1993; Kanthan \& Mills, 2006) and to read and evaluate medical literature and answer their patients' queries (Mungra, 2007; Shokoui \& Isazadeh, 2009). The researcher identified the importance of metaphor-based instruction from the results of questionnaire and will implement it in future. 


\section{References}

Broyard, A. (1990, March 31). Good Books About Being Sick. The New York Times. https://www.nytimes.com/1990/04/01/books/good-books-abut-being-sick.html Accessed 1 Oct. 2017.

Casarett, David, Amy Pickard, Jessica M. Fishman, Stewart C. Alexander, Robert M. Arnold, Kathryn I. Pollak \& James A. Tulsky. (2010). Can metaphors and analogies improve communication with seriously ill patients? Journal of Palliative Medicine 3(3), 255-260. https://doi.org/10.1089/jpm.2009.0221

Danesi, M. (1992). Metaphor and classroom second language learning. Romance Languages. Annual 3, 189-193.

Geary J. (2011). I Is an Other: The Secret Life of Metaphor and How It Shapes the Way We See the World. New York, NY: Harper Perennial.

Johnson, J. \& Rosano, T. (1993). Relation of cognitive style and second language proficiency. Applied Psycholinguistics, 14(2), 59-175. https://doi.org/10.1017/S014271640000953X

Kanthan, R. \& Sheryl M. (2006). Using metaphors, analogies and similes as aids in teaching pathology to medical students. Journal of the International Association of Medical and Science Education, 16(1), 19-26. $\mathrm{http} / / / \mathrm{www}$.iamse.org/mse-article/using-metaphors-analogies-and-similes-as-aids-in-teaching-pathology-tomedical-students/

Kecskes, I. (2006). On my mind: Thoughts about salience, context and figurative language from a second language perspective. Second Language Research, 22(2), 1-19. https://doi.org/10.1191/0267658306sr266ra

Knudsen, S. (2005). Communicating novel and conventional scientific metaphors: a study of the development of the metaphor genetic code. Public Understanding of Science, 14(4), 373-392. https://doi.org/10.1177/0963662505056613

Lakoff, G. \& Johnson, M. (1980). Metaphors we live by. Chicago: University of Chicago Press.

Lakoff, G. \& Johnson, M. (2003). Metaphors we live by. London: The University of Chicago Press. https://doi.org/10.7208/chicago/9780226470993.001.0001

Mungra, P. (2007). Metaphors among titles of medical publications: An observational study. Iberica. 14 (Fall 2007), 99-122. https://www.redalyc.org/pdf/2870/287024055006.pdf

Reisfield, G. M. \& George R. W. (2004). Use of metaphor in the discourse of cancer. Journal of Clinical Oncology, 22(19), 4024-4027. https://doi.org/10.1200/JCO.2004.03.136

Roche, C. J., David P. O'Keeffe, Kit W. L., Vinay, A. D, William C. T. \& John M. C. (2002). Selections from the buffet of food signs in radiology. Radio Graphics, 22(6), 1369-1384. https://doi.org/10.1148/rg.226025521

Shokouhi, H. \& Isazadeh, M. (2009). The effect of teaching conceptual and image metaphors to EFL learners. The Open Applied Linguistics Journal, (2), 22-31. https://doi.org/10.2174/1874913500902010022

Sontag, Susan (1978). Illness as metaphor. New York: Farrar, Strauss \& Giroux.

Vyjeyanthi, P. S. (2008). Using metaphors in medicine. Journal of Palliative Medicine, 11(6), 842-844. https://doi.org/10.1089/jpm.2008.9885

Wei Y. Z. (2007). An Investigation into the Roles of Cognitive Ability and Language Proficiency in Chinese EFL Learners' Metaphor Comprehension and Production. [doctoral dissertation]. Guangxi Normal University, China.

\section{Copyrights}

Copyright for this article is retained by the author(s), with first publication rights granted to the journal.

This is an open-access article distributed under the terms and conditions of the Creative Commons Attribution license (http://creativecommons.org/licenses/by/4.0/). 